\title{
Industry-Specific Antitrust Policy for Innovation ${ }^{1}$
}

\author{
Mark A. Lemley ${ }^{2}$
}

The complex interaction between intellectual property (IP) and antitrust law has variously been called a conflict, an intersection, a relationship, a tension, an interaction, an interface, and most simply, "and." The early view of the relationship between the two emphasized the conflict between (to oversimplify in both directions) a law that grants monopolies and a law that forbids them. But beginning in the 1970s, that view was challenged by Ward Bowman and others, who argued that both IP and antitrust law serve the long-run goal of efficiency, albeit in different ways. ${ }^{3}$ That view led to a new orthodoxy, under which courts and commentators perceived little or no tension between IP and antitrust. Antitrust promoted static efficiency by reducing deadweight loss, while IP promoted dynamic efficiency by reducing costs and opening new markets.

Under this new orthodoxy, it was quite natural for antitrust to slip into a subsidiary role vis-à-vis antitrust. If the two really operated in separate domains, after all, antitrust shouldn't interfere with the operation of the IP laws, but should stay in its own territory. And as the IP laws expanded over the last several decades, antitrust accordingly receded, ceding ground to IP rather than reigniting a "conflict" that after all wasn't supposed to exist.

1 (C) 2010 Mark A. Lemley.

2 William H. Neukom Professor, Stanford Law School; partner, Durie Tangri LLP, San Francisco, California. Thanks to participants at the Stanford-ABA Conference on Antitrust and Innovation for comments on an earlier draft.

3 Ward S. Bowman Jr., Patent and Antitrust Law: A Legal and Economic Appraisal (1973). 
More important, if IP and antitrust were dividing up turf, IP clearly got first pick. Think for a moment about whether static or dynamic efficiency is a more important driver of our economy, and the answer will be obvious. We benefit from market competition in existing products, but we benefit far more from the development of new products. Ask yourself whether you'd rather be the richest person in the world in 1700 or an average citizen of the U.S. in 2010. Unless you have surprisingly little love for transportation, communication, sanitation, and indoor plumbing, you'll probably pick your average life today. Closer to today, ask yourself whether you would rather have a monopolistically-priced iPod or a perfectly competitive market for 8-track tapes. While Joe Miller has argued that "patent ships sail an antitrust sea" ${ }^{\prime 4}$ - that patents are small exceptions from the norm of antitrust - in fact it is IP and not antitrust that seemed the more important driver of our market economy of late. And that fact is traceable to the ground each has claimed. IP is more important because it stands for dynamic efficiency, which is simply more important to our society than static efficiency.

But that premise - that IP promotes dynamic efficiency while antitrust concentrates on static welfare - is wrong, or at least oversimplified. It proceeds from a fundamentally Schumpeterian assumption that competition will not lead to innovation, and we need the lure of monopoly to drive investment in new products. In fact, however there is substantial economic evidence suggesting that competition itself may act as a greater spur to innovation than monopoly. ${ }^{5}$ Monopolists can be lazy or foolish, and when they are there is little to

4 Joseph Scott Miller, Patent Ships Sail an Antitrust Sea, 30 Seattle U. L. Rev. 395 (2007).

5 Ken Arrow has long been associated with this position. See Kenneth J. Arrow, Economic Welfare and the Allocation of Resources for Invention, in Nat'I Bureau of Econ. Research, The Rate and Direction of Inventive Activity: Economic and Social Factors 609, 615 (1962). For a review of the economic evidence 
constrain their foolishness. They may also have structural incentives to invest less in the sort of disruptive innovations that, even if they enhance social welfare, primarily cannibalize the monopolist's existing market.

Further, there is good evidence that IP rights do not always promote innovation. Sometimes they interfere with innovation, particularly if the rights are too strong or last too long, so that generation after generation of potential improvers must get permission from one (or, worse, many) existing stakeholders before innovating in a field.

The relationships between IP and innovation on the one hand, and between antitrust and innovation on the other, are accordingly more complex than normally assumed. IP sometimes promotes dynamic efficiency, but can also impede it. Antitrust too sometimes - but not always - promotes dynamic efficiency. ${ }^{6}$

If I am correct that competition, not just monopoly, can sometimes serve as a spur to innovation, the use of antitrust law to encourage innovation exists in considerable tension with the use of IP rights to achieve the same end. If the law is to encourage innovation in a particular industry, it must choose among IP, antitrust, or some combination of the two to do so. This choice doesn't have to be universal; there is good reason to believe that IP rights work better in some circumstances and competition in others. ${ }^{7}$ But it does have to be made: IP and competition frequently work towards the goal of innovation at cross purposes.

supporting this position, see Mark A. Lemley, Property, Intellectual Property, and Free Riding, 83 Tex. L. Rev. 1031 (2005).

6 For a detailed discussion, see 1 Herbert Hovenkamp et al., IP and Antitrust ch. 1 ( 2 d ed. 2010).

7 See, e.g., Dan L. Burk \& Mark A. Lemley, Policy Levers in Patent Law, 89 Va. L. Rev. 1575 (2003). 
In fact, however, the situation is more complex still. A wealth of economic evidence suggests that innovation is far from a unitary phenomenon. More specifically, innovation differs dramatically by industry. Dan Burk and I have explored this in detail in a recent book; the reader is referred there for a discussion of the evidence. ${ }^{8}$ To see the scope of the problem, think about the very different characteristics of just two industries: small-molecule chemistry and Internet business methods.

\section{Pharmaceuticals and Schumpeterian Innovation}

Schumpeterian prospect theory is based on the premise that strong IP rights should be given to a single coordinating entrepreneur. Prospect theory envisions invention as something done by a single firm, rather than collectively; as the result of significant expenditure on research, rather than the result of serendipity or casual experimentation; and as only the first step in a long and expensive process of bringing a product to market, rather than as an activity

close to a final product. ${ }^{9}$ Prospect theory follows Joseph Schumpeter in distinguishing between the act of invention, which creates a new product or process, and the broader act of innovation, which includes the work necessary to revise, develop, and bring that new product or process to commercial fruition. As a result, prospect theory suggests that patents should be broad, stand alone, and confer almost total control over subsequent uses of the product.

The prospect vision of patents maps most closely onto invention in the pharmaceutical industry. Pharmaceutical innovation is notoriously expensive and time-consuming. The

8 Dan L. Burk \& Mark A. Lemley, The Patent Crisis and How the Courts Can Solve It ch. 4-5 (2009). Portions of the next few paragraphs are adapted from chapter 7 of that book.

${ }^{9}$ See Richard R. Nelson \& Sidney G. Winter, An Evolutionary Theory of Economic Change 263 (1982). 
pharmaceutical industry reports that it spends as much as $\$ 800$ million on research and development (R\&D) (including product development) for each new drug produced. ${ }^{10}$ That number is almost certainly inflated, including among other things substantial marketing expenditures that should not count as part of $R \& D$, but there is no doubt that R\&D is extremely expensive in the pharmaceutical industry. ${ }^{11}$ The industry spends over $\$ 30$ billion a year in private R\&D, more than the total budget of the National Institutes of Health. ${ }^{12}$ Furthermore, inventing a new drug is only the beginning of the process, not the end. The Food and Drug Administration requires a lengthy and rigorous set of tests before companies can release drugs to the market. ${ }^{13}$ The Pharmaceutical Research and Manufacturers of America estimates that the total time spent from the beginning of a research project to the marketing of a successful drug is twelve to fifteen years, 1.8 years of which is due to the FDA approval process. Although imitation of a drug is reasonably costly in absolute terms, a generic manufacturer that can prove bioequivalency can avoid almost all of the R\&D cost and can get FDA approval much more quickly than the original manufacturer. The ratio of inventor cost to imitator cost, therefore, is quite large in the absence of effective patent protection. As a result, it is likely that innovation would drop substantially in the pharmaceutical industry in the absence of effective

\footnotetext{
${ }^{10}$ See Gardiner Harris, “Cost of Developing Drugs Found to Rise," Wall St. J., Dec. 3, 2001, at B14.

${ }^{11}$ Estimates of the average cost of drug development and testing range from $\$ 110$ million to $\$ 803$ million; the latter is the industry's figure. Compare Pharm. Res. and Mfrs. of Am., "Why Do Prescription Drugs Cost So Much and Other Questions about Your Medicines," at http://www.phrma.org/publications/publications/brochure/questions/ (2000), with Pub. Citizen, "Rebuttals to PhRMA Responses to Public Citizen Report Rx [Research and Development] Myths: The Case against the Drug Industry's 'Scare Card,' $\langle\mathrm{ts}\rangle$ " at http://www.citizen.org/congress/reform/drug_industry/corporate/articles.cfm?ID=6514 (last visited Aug. 13, 2003) (criticizing industry estimates and offering the lower figure).

${ }^{12}$ Stuart Luman, "Strong Medicine," Wired, June 2004, at 150.

${ }^{13}$ See http://www.phrma.org/publications/publications/brochure/questions/. Other estimates range from seven to fifteen years. See Richard J. Findlay, Originator Drug Development, 54 Food \& Drug L.J. 227, 227 (1999).
} 
patent protection. ${ }^{14}$ And indeed a wealth of empirical evidence finds that patents are extremely important to innovation in pharmaceuticals. ${ }^{15}$ James Bessen and Michael Meurer go so far as to argue that the evidence suggests that patents are worth the cost only in the pharmaceutical and chemical industries. ${ }^{16}$

Patents also map well onto products in the pharmaceutical industry. As a general rule, the scope of patents in the pharmaceutical industry tends to be coextensive with the products actually sold. Pharmaceutical patents do not merely cover small components that must be integrated into a marketable product, and this in turn means that a company that wishes to sell a pharmaceutical product generally won't need licenses for many different patents. ${ }^{17}$ Chemicals are readily characterized using existing scientific terminology, so people can generally tell what a pharmaceutical patent covers, unlike patents in the information technology industries. Drugs generally have stable effects, meaning that significant improvement in a pharmaceutical product is likely to take the form of finding a new drug rather than somehow building on an existing one. And the fact that structurally related chemicals (called homologs) often have similar effects means that if patents do not cover a group of related products, imitators can easily design around the patent by employing a close chemical analog to the patented drug.

\footnotetext{
${ }^{14}$ See, e.g., James W. Hughes et al., "Napsterizing" Pharmaceuticals: Access, Innovation, and Consumer Welfare (Nat'I Bureau of Econ. Res. Working Paper No. 9229, 2002).

${ }^{15}$ Cohen \& Merrill, supra, at 12 ("Economic research has made a convincing case that in at least one area--pharmaceuticals-- patents have played a critical role in stimulating technical advance"). ${ }^{16}$ James Bessen \& Michael Meurer, Patent Failure: How Judges, Bureaucrats, and Lawyers Put Innovators at Risk (2008).

${ }^{17}$ Although pharmaceutical companies have tried to find ways to obtain multiple patents on the same basic invention in an effort to extend the life of their patents, these efforts are aberrations that represent a failure of the system, not its normal function. See Lara J. Glasgow, Stretching the Limits of Intellectual Property Rights: Has the Pharmaceutical Industry Gone Too Far?, 41 Idea 227, 233-35 (2001). The patent doctrine of "double patenting" is designed to prevent this sort of abuse. See, e.g., Eli Lilly \& Co. v. Barr Labs., 251 F.3d 955, 967-68 (Fed. Cir. 2001).
} 
All of these factors suggest that innovation in the pharmaceutical industry requires strong patent rights. ${ }^{18}$ In the pharmaceutical industry, there is no serious problem of either cumulative or complementary innovation. Strong patent rights are necessary to encourage drug companies to expend large sums of money on research years before the product can be released to the market. And because much of the work occurs after the drug is first identified, it is important to give patentees the right to coordinate downstream changes to the drug so they can recoup the costs of that additional work. Some empirical evidence supports this result. Patents in the chemical and pharmaceutical industries were more likely to be licensed ex ante-a central facet of prospect theory--than patents in any other field. ${ }^{19}$ Prospect theory works in the pharmaceutical industry.

\section{The Internet and Competitive Innovation}

The theory of competitive (or at least imperfectly competitive) innovation focuses on the incentives companies have to innovate even if they do not hold a monopoly position and are unlikely to acquire one through innovation. This approach emphasizes the fact that many inventions do not require substantial and sustained R\&D expenditures; they may be relatively simple ideas or discoveries happened upon serendipitously. It is also premised on competition's role in improving products and on the existence of other incentives to innovate, such as lead time or government research funding. And it worries that strong patent rights will stifle subsequent generations of innovation, locking the world into version 1.0 of a product - fine,

18 To be sure, this may be a function of the regulatory structure we have build around the industry, which itself contributes to the cost and delay associated with pharmaceutical innovation.

${ }^{19}$ B. N. Anand \& T. Khanna, The Structure of Licensing Contracts, 48 J. Indus. Econ. 103 (2000). 
perhaps, in pharmaceuticals, where cumulative innovation is infrequent, but not the way many other industries work.

Competitive innovation theory maps well onto a variety of industries that have experienced substantial innovation in the absence of patent protection. One notable example is business methods. Under long-standing precedent, business methods were excluded from patent protection. ${ }^{20}$ That changed in 1998, when the Federal Circuit concluded that business methods were patentable and, indeed, always had been. ${ }^{21}$ As many commentators have noted, however, companies have ample incentives to develop business methods even without patent protection, because the competitive marketplace rewards companies that use more efficient business methods. ${ }^{22}$ Even if competitors copy these methods, first-mover advantages and branding can provide rewards to the innovator. ${ }^{23} \mathrm{FedEx}$, for instance, has preserved substantial market share in the overnight package delivery market despite entry into the market by other companies that copied its business model. Because new business methods do not generally require substantial investment in $R \& D$, the prospect of even a modest supracompetitive reward will provide sufficient incentive to innovate. This does not mean business methods can never be

\footnotetext{
${ }^{20}$ See, e.g., Hotel Security Checking Co. v. Lorraine Co., 160 F. 467 (2d Cir. 1908). See also Alan L. Durham, "Useful Arts" in the Information Age, 1999 B.Y.U. L. Rev. 1419; John R. Thomas, The Patenting of the Liberal Professions, 40 B.C. L. Rev. 1139 (1999).

${ }^{21}$ See State St. Bank \& Trust v. Signature Fin. Group, 149 F.3d 1368 (Fed. Cir. 1998). The United States is the only country to patent business methods. See, e.g., William van Caenegem, The Technicality Requirement, Patent Scope and Patentable Subject Matter in Australia, 13 Austr. Intell. Prop. J. 41, 41 (2002).

${ }^{22}$ See, e.g., Rochelle C. Dreyfuss, Are Business Method Patents Bad for Business?, 16 Santa Clara Comp. \& High Tech. L.J. 263 (2000); Robert P. Merges, Patent Law and Policy 155 (2d ed. 1997). But cf. Mark A. Lemley et al., Software and Internet Law 317-21 (3d ed. 2006) (discussing the debate over whether business method patents encourage innovation).

${ }^{23}$ Cf. Mark A. Lemley \& David W. O'Brien, Encouraging Software Reuse, 49 Stan. L. Rev. 255, 274-75 (1997).
} 
sufficiently innovative to deserve protection, but it does mean that patenting every new business practice is unnecessary and probably socially harmful.

Similarly, innovation has flourished in other industries in the absence of patent protection. The early history of the software industry is one in which innovators developed impressive new products at very little cost in the absence of patent protection. ${ }^{24}$ Patent protection was not available for software until well into the 1980 s. Copyright protection may have been available, though the applicability of copyright was not really settled until Congress amended the statute in 1980 . Some have argued that software should not be patentable even today, ${ }^{25}$ though that argument ignores some economic changes in the industry and in any event seems unlikely to prevail. More recently, the Internet developed without patent protection for its fundamental protocols, in part because it was based on government-funded work and in part because the academic developers simply did not seek patent protection. A number of scholars have argued that the open, nonproprietary nature of the Internet is directly responsible for the dramatic innovation it fostered in the 1990s. They point out that AT\&T, which had a monopoly in telephony and therefore under prospect theory the right incentives to innovate in the field, did not engage in similar innovation. ${ }^{26}$ Open protocols permitted competition, and competition drove innovation. This too is changing, not because of differences in the economic structure of the Internet but because patent owners have flocked

\footnotetext{
${ }^{24}$ See Julie E. Cohen \& Mark A. Lemley, Patent Scope and Innovation in the Software Industry, 89 Calif. L. Rev. 1, 7-16 (2001).

${ }^{25}$ See, e.g., Michele L. Boldrin \& David K. Levine, Against Intellectual Monopoly (2008); League for Programming Freedom, Software Patents: Is This the Future of Programming? Dr. Dobb's J., Nov. 1990, at 56.

${ }^{26}$ See Mark A. Lemley \& Lawrence Lessig, The End of End-to-End: Preserving the Architecture of the Internet in the Broadband Era, 48 UCLA L. Rev. 925 (2001).
} 
in droves to try to control various aspects of the Internet.

Competitive innovation theory suggests that ownership is not a necessary prerequisite to innovation, and indeed that it is sometimes inimical to innovation. Patent protection is not always appropriate, particularly where expected R\&D cost is small, where the ratio of innovator cost to imitator costs is small, or where first-mover advantages or network effects can provide the needed incentives. Under these conditions, patents should be rare and very modest in scope, in order to allow market forces their fullest latitude. Competitive innovation theory fits business methods, arguably fits the Internet, and--at least in the 1970s--fit software.

In sum, then, the problem then is not simply that we must choose between a monopolybased and a competition-based theory of innovation. It is that the right answer will differ depending on the industry, and on the nature of the invention within each industry.

In our book, Dan Burk and I suggested that the way for patent law to deal with the industry-specific nature of both innovation and the role of patents in that innovation was to treat inventions in different industries differently. ${ }^{27}$ We argued not for industry-specific patent statutes - those are likely to suffer from a host of rent-seeking and definitional problems - but for a nominally unitary set of legal standards that can be applied differently in different technologies and different industries.

If antitrust as well as IP serves the goal of innovation policy, and if antitrust as well as IP varies in its efficacy by industry, the question is whether antitrust as well as IP law should be

27 Burk \& Lemley, The Patent Crisis, supra note _ , at _. 
industry-specific. I suggest that it should. In particular, I think courts should take the importance of competition in promoting innovation into account in setting IP-antitrust policy.

Antitrust law is almost entirely a creature of the courts. While it is based on animating statutes, they set out only the most basic of principles. It has fallen to the courts to articulate even the most fundamental antitrust rules. And in doing so, both the courts and the agencies have applied what Dan Burk and I call "micro policy levers." That is, they have focused on the economic characteristics of the individual industry before them. Antitrust cases in the software industry focus on network effects and the dominance they produce; antitrust cases in the pharmaceutical industry focus on potential competition and the barriers to entry that result from entry regulation; antitrust cases in the hospital industry focus on the complex web of relationships between hospitals and medical practice groups. This industry specificity results from the nature of antitrust, which - far more than patent law - is concerned with the particular economic characteristics of both the practice being regulated and the market in which the practice occurs.

Indeed, the industry-specific nature of the antitrust inquiry is so ingrained that government antitrust authorities organize themselves along industry lines. The Federal Trade Commission and the DOJ Antitrust Division divide authority, not along doctrinal lines (mergers to one agency, monopolization to another), but by parceling authority over some industries to each agency. And within the Antitrust Division, authority is further divided within the civil sections by industry group. This institutional structure reflects the fact that knowing an 
industry in detail is often more important in antitrust law than knowing a particular body of law in detail.

It should be no surprise, then, that antitrust law has begun to develop industry-specific rules at both a macro- and a micro-level. While some such rules are legislated - the exemptions for the insurance industry and for railroads are obvious examples - others are judicially created. The D.C. Circuit created a separate tying doctrine just for computer operating systems. ${ }^{28}$ The courts long ago created a separate set of legal rules to deal with collective bargaining by labor unions. ${ }^{29}$ And courts have sometimes applied expressly industry-specific doctrines to heavilyregulated industries like pharmaceuticals, banking, and telecommunications. ${ }^{30}$

Besides these macro policy levers, courts have applied nominally neutral antitrust doctrines in different ways in different industries. Mergers are treated differently in shrinking industries than in growing ones. ${ }^{31}$ Health care seems to have developed its own body of case law that interacts very little with cases in other industries. ${ }^{32}$ So too with the durable goods aftermarket cases. And the Internet and the credit card industry have both spawned a series of antitrust investigations with network effects at their core.

When it comes to IP, however, that contextual, industry-specific approach to antitrust law seems to disappear. Antitrust law defers to patent law within the scope of the patent right,

28 U.S. v. Microsoft Corp., 253 F.3d 34 (D.C. Cir. 2001) (en banc).

29 See, e.g., Connell Constr. Co. v. Plumbers and Steamfitters Local Union No. 100, 421 U.S. 616, 625 (1975).

30 For a critical discussion of these cases, see, e.g., Stacey L. Dogan \& Mark A. Lemley, Antitrust Law and Regulatory Gaming, 87 Tex. L. Rev. 685 (2009).

31 U.S. v. General Dynamics Corp., 415 U.S. 486 (1974).

32 See, e.g., Peter J. Hammer, The Architecture of Healthcare Markets: Economic Sociology and Antitrust Law, 7 Hous. J. Health L. \& Pol'y 227 (2007). 
largely contenting itself with policing the edges of that right to make sure that parties do not expand that right beyond its scope with anticompetitive effect. ${ }^{33}$ And increasingly antitrust doesn't even do that, deferring to settlements even of "fatally weak" patent claims ${ }^{34}$ and withdrawing entirely from the regulation of conditions unilaterally imposed on a patent licensee. ${ }^{35}$ The result is that it is patent law, not antitrust law, that determines how innovation will be protected.

If I am right that the relationship between market structure and innovation is industryspecific, we need a more nuanced innovation policy. We should have strong patent rights in circumstances in which we believe Schumpeter is right and innovation requires investment or reward that cannot be achieved in a competitive market. But we should have strong antitrust policy in circumstances in which we believe Arrow is right and it is competition rather than monopoly that will drive innovation.

If patent law were properly calibrated to the characteristics of different industries, it might get us to this goal as a practical matter. Since antitrust policies the boundaries of the patent right, antitrust may expand in precisely those circumstances in which patent law recedes. So if patent law properly steps back in industries in which monopoly is not necessary or desirable to promote innovation, antitrust law might be expected to rush in. Certainly that ebb-and-flow relationship has happened throughout history, with antitrust growing stronger in the eras in which patent law grows weaker. That historical relationship was unproductive,

33 The exceptions - Walker Process fraud claims and sham litigation - are narrow and rarely successful. See 1 Herbert Hovenkamp et al., IP and Antitrust ch 11 (2d ed. 2010).

34 See, e.g., In re Tamoxifen Citrate Antitrust Litig., 466 F.3d 187, 212 (2d Cir. 2005).

35 CSU v. Xerox, 203 F.3d 1322 (Fed. Cir. 2000). But see Image Technical Servs. v. Kodak, 125 F.3d 1195 ( $9^{\text {th }}$ Cir. 1997). 
because it led to cycles of over- and under-protection. ${ }^{36}$ But if we could harness that relationship on an industry-specific basis, it might lead, not to vacillation between all-patent and all-antitrust eras, but to areas of patent primacy and areas of antitrust primacy.

The harder question is how antitrust law should react when patent law gets this balance wrong. Understanding antitrust law as a promoter of innovation within its own domain argues, I think, for a more affirmative role for antitrust. Antitrust should be more willing to confront patent law directly in those industries in which we are confident that competition rather than monopoly spurs innovation and in which patent law has not recognized that fact. ${ }^{37}$ This may mean that antitrust law sometimes constrains conduct that is within the scope of the patent right. Antitrust might, for instance, impose restrictions on patent pools in industries in which we think competition is important, driving competitors to litigate the validity and infringement of patents that would otherwise have been included in the pool. Or it might limit the acquisition of an array of patents that fence off a particular field such as a new business model. It might constrain the ability of patent owners to condition the license of their IP rights on a restriction in other forms of competition. Most radically, it might restrain the enforcement of patent rights themselves where that enforcement will prevent competition. For example, antitrust could restrict the application of injunctive relief, as it does outside IP in the essential facilities context.

36 Mark A. Lemley, A New Balance Between IP and Antitrust, 13 Sw. J. L. \& Trade Ams. 237 (2007). 37 The same might be true with respect to other IP rights. See, e.g., Deven R. Desai \& Spencer Waller, Brands, Competition, and the Law (working paper 2010 (arguing that antitrust has failed to confront the problematic increase in power given trademark owners); Glynn S. Lunney Jr., Trademark Monopolies, 48 Emory L.J. 367 (1999). But because those arguments depend on other theories than the role of antitrust in promoting innovation, I do not discuss them further here. 
This is, to be sure, a controversial proposition. I would probably not go so far as to apply the essential facilities doctrine to IP rights, for instance. ${ }^{38}$ And the preferable alternative is surely for patent law to restrict itself in those industries. But the point remains: antitrust law has a claim to co-equal status with patent law as a promoter of innovation, and the interaction between the two should reflect that status. If competition will promote innovation in a particular instance, antitrust, not patent law, must stand up for innovation.

38 See, e.g., 1 Herbert Hovenkamp et al., IP and Antitrust $\S 13.3 c 2$ (2d ed. 2010) (arguing against application of the essential facilities doctrine to IP rights). 